\title{
ThIAS (Thief Indication Alarm System) Security Device of Livestock in Animal Cages Based on Light Dependent Resistor (LDR) and Microcontroller Arduino
}

\author{
Aji Rahmadi", Adi Ahmad Dimisa **, Asep Kurniawan ${ }^{* * *}$, Frida Agung Rakhmadi**** \\ Physics Department, Faculty of Science and Technology, UIN Sunan Kalijaga \\ J1. Marsda Adisucipto No. 1 Yogyakarta 55281, Indonesia. Tel. + 62-274-540971, Fax. + 62-274-519739 \\ Email: ajirahmadi64@gmail.com*, adi.ahmad.dimisa@gmail.com ${ }^{* *}$, asep.guncil@gmail.com ${ }^{* * *}$, frida.rakhmadi@uin-suka.ac.id ${ }^{* * * *}$
}

\begin{abstract}
Research on Thias (Thief Alarm Indication System) safety device of livestock in animal cages based on the Light Dependent Resistor (LDR) and the Arduino microcontroller has been done. This research aims to design and characterize an alarm system or test the success rate of the alarm system. This study can be used as an alarm when livestock theft is occurring. The method used in this research is divided into three stages, design, manufacture and testing. The working principle of this alarm system, when the laser beams hitch the LDR, then the high value of the resulting LDR then produces an alarm notification in the form of sound. The hitch here is a thief entering or exiting the cage. To control the performance of the alarm system use the Arduino microcontroller. Obtained results from this research is a prototype alarm system. From testing, this alarm system obtained a success rate of $100 \%$. The advantages of this alarm system are cheap and simple.
\end{abstract}

Keywords: Alarm, LDR, Livestock, Theft

\section{INTRODUCTION}

According to Statistic Center of Sleman Regency (2017), the number of robberies that occurred in the year 2014 to 2016 is divided into several categories. Cases of theft by weighting decreased from 297 to 256 cases. Cases of theft accompanied by violence also decreased from 69 cases to 54 cases. But in the case of theft of a light level - the usual increased from 195 to 31 cases. Different from Sleman regency, Malang regency has a number of crimes more. According to Statistic Center of Malang Regency (2017), the number of theft cases occupied most motorcycle thefts that are 2437 cases and the largest number of cases in 2016 that is 1187 the number of theft cases.

One of the disturbing resident's theft is theft of livestock. Launched in SindoNews.com (2017) is based on the profit motive of the stolen animal's sale is very profitable. The profit after selling stolen livestock can reach millions of rupiah. Surely livestock owners will get a big loss. Reported by the Media Indonesia (2017) other thefts can give a loss to tens of millions of rupiah. Not surprisingly, the theft is rife with the background of profit in the sale of the livestock.

According to Muh. Fauzi Ridwan (2017) Mode of theft is damaging the cages. The thieves damaged the cages by prying the door or break the lock using a machete. Launched in SindoNews (2017) also explained that the thieves were enveloped the livestock with a cloth so as not to make a sound.
The security system that can be used is Thias (Thief Alarm Indication System). This tool system not much different from what has been done by another researcher, namely using LDR sensor as an intruder detection device. Named the alarm system as a function of this tool is a warning alarm when a thief or intruder entrance to the corral. The speakers are connected to this device will sound when there is a thief is detected by the sensor LDR. To connect the speakers to the required device telemetry system in the form of nRF24L01. It is intended to cage which has a distance away from the house owner, can be connected without wires so that the system becomes a simpler tool.

\section{MATERIALS AND METHODS}

\section{Tools and materials}

Materials to be used in the manufacturing of alarm systems is shown in Table 1.

Table 1. List of materials for manufacturing.

\begin{tabular}{ll}
\hline Material & Number/Description \\
\hline Arduino Nano & 2 pieces \\
NRF Transmitter & 1 piece \\
NRF Receiver & 1 piece \\
Buzzer & 1 piece \\
BOX & 2 pieces \\
Laser & 1 piece \\
Sensor LDR & 1 piece \\
$9 V$ power supply & 1 piece \\
\hline
\end{tabular}


In the manufacturing of alarm systems requires tools is shown in Table 2.

Table 2. List of tools for manufacturing.

\begin{tabular}{ll}
\hline Tools & Number / Description \\
\hline Laptop & 1 Unit \\
Arduino application & 1 piece \\
Power Drills & 1 piece \\
Solder & 1 piece \\
Cutter & 1 piece \\
Hacksaw & 1 piece \\
Scissor & 1 piece \\
Screwdriver & 1 piece \\
Jumper cables & Sufficiently \\
\hline
\end{tabular}

\section{Manufacturing of Alarm System}

Manufacturing of the alarm system is divided into two stages. Steps being taken include the manufacture of alarm systems and alarm system testing. General manufacturing procedures are shown in Figure 1.

Manufacturing of Alarm $\rightarrow$ Testing of Alarm

Figure 1. Block diagram of the manufacturing procedure.

Producing an alarm system in this manufacturing of system are two circuits that are used in that circuit are Transmitter and Receiver circuit. Details of the manufacturing of the alarm system are as Figure 2.

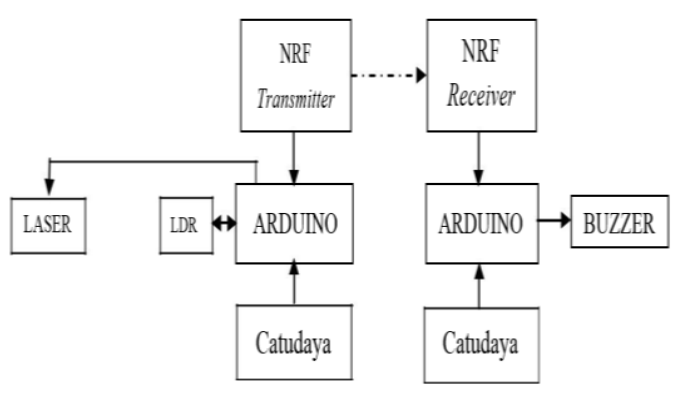

Figure 2. The block diagram of an alarm system.

Transmitter circuit is a circuit that serves to cultivate the sensor and transmit data. The process of making the transmitter circuit consists of programming and assembly of the alarm system. Programming of the system in the Arduino IDE software, while the Arduino IDE programming process in accordance with the flowchart shown in Figure 3. Receiver circuit is a circuit that serves as a receiver signal from the Transmitter. Receiver circuit assembly of the alarm system. Programming system in the Arduino IDE software, while the Arduino IDE programming process in accordance with the flowchart shown in Figure 4.

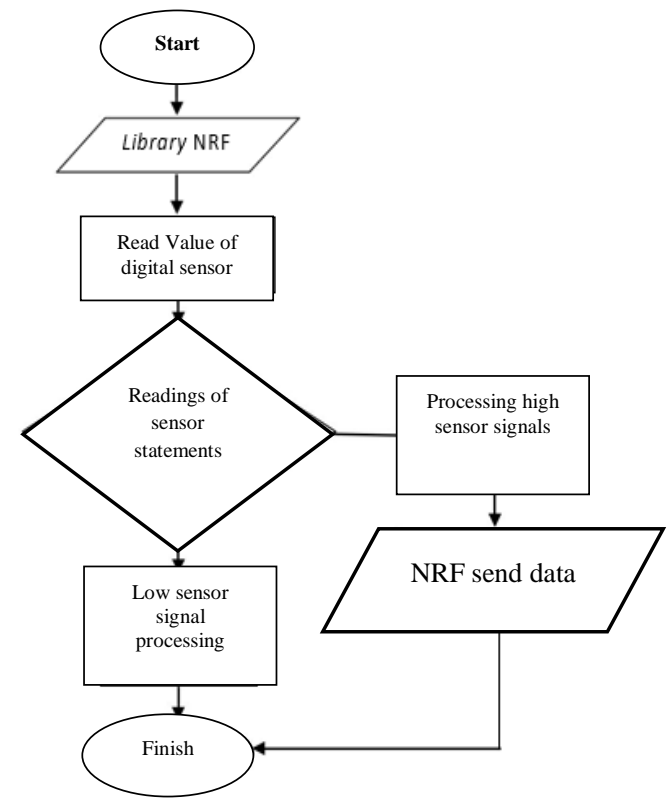

Figure 3. Transmitter circuit flowchart.

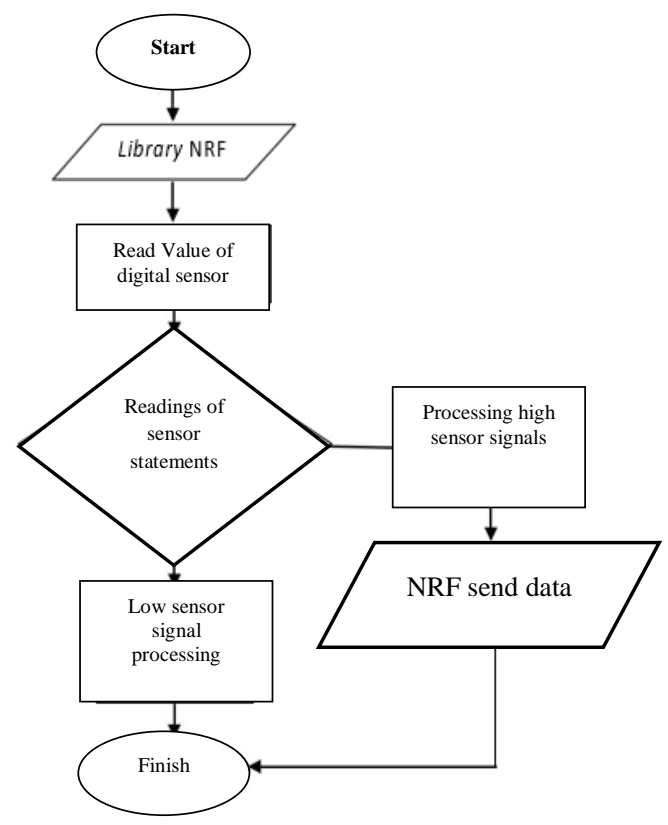

Figure 4. Flowchart series of receiver.

\section{Testing of Alarm System}

The testing of alarm system is 3 times of testing system with a variety of testing time every 30 minutes within 12 hours with a data capture system is dead or alive. This test aims to determine the level of success and precision alarm system are made. The amount of precision alarm system can be obtained by the equation, where $\Delta x$ is the greatest deviation and Fs is the maximum output.

$\%$ Presisi $=100 \%-\left[\frac{\Delta x}{F_{s}} \times 100 \%\right]$ 


\section{RESULTS AND DISCUSSION}

\section{Manufacture of Alarm System}

Livestock theft alarm system or Thias (Thief Indication Alarm System) has been created and is shown in Figure 5.

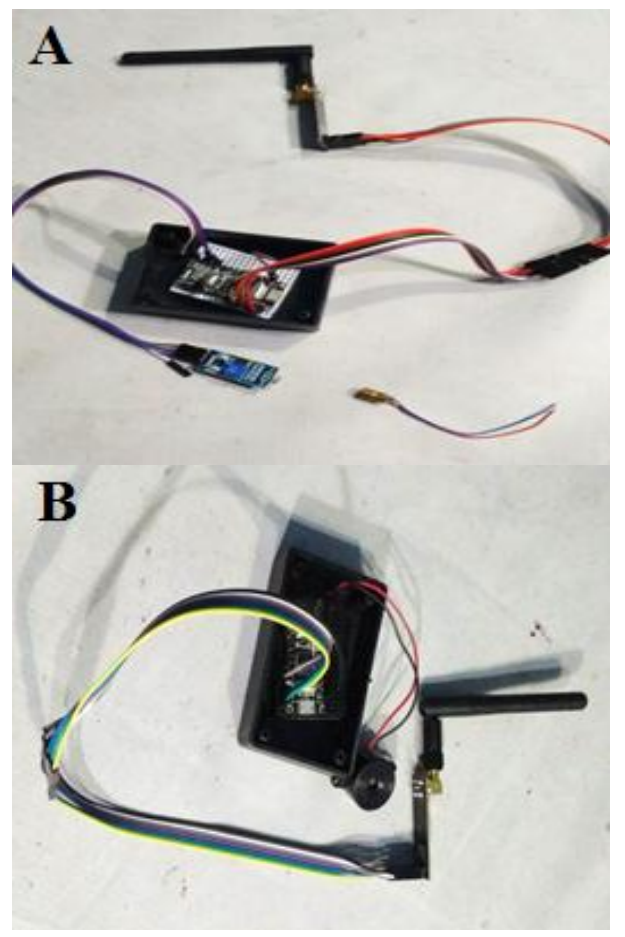

Figure 5. Alarm systems (a) Circuit transmitter (b) Receiver circuit.

The system is mounted on the door of the cage with laser and sensor positions opposite. When the system is turned on, the laser will illuminate the sensor and the system will off. If there is a hitch (thieves) then the laser will be disconnected from the sensor and the system will send a signal through the transmitter and received by the receiver. Receiver will receive the input signal and a buzzer will sound. To overcome that system does not off when the laser illuminated the sensor again after laser by passed by thief, then the system is programmed to turn on after being given a hitch.

\section{Testing of Alarm Systems}

Testing the alarm system by varying the test 3 times every 30 minutes during the 12 hours of data obtained as many as 25 data. At each hitch, alarm system will on. Thus, of the test, success rate of the alarm system is $100 \%$. From the results of testing the system there is no failure and no deviations of data. Then by the equation 1 , precision of the alarm system is $100 \%$.

\section{CONCLUSIONS}

The working principle of the alarm system is when the laser beams hitch the LDR, then the high value of the resulting LDR then produces an alarm notification in the form of sound. The hitch here is a thief entering or exiting the cage. To control the performance of the alarm system use the Arduino microcontroller. Obtained results from this research is a prototype alarm system. Testing the alarm system by varying the test 3 times every 30 minutes during the 12 hours of data obtained as many as 25 data. At each hitch, alarm system will on. From testing, this alarm system obtained a success rate of $100 \%$ and has the advantages that is cheap and simple.

\section{REFERENCES}

BPS. 2017. Number of Crimes that Standout In Sleman 2014-2015. Sleman: Statistics Sleman.

2017. Number of Reported Crime and Completed by Type of Crime In Malang 2014-2015. Malang: The Malang Statistics Agency.

Fauzi, Muh. R. Republika. December 11, 2017.http://nasional.republika.co.id/berita/nasional/daerah/17/12 /11/p0sph5280-polisi-bekuk-sindikat-pencurian-ternak-dengangunakan-karung (Accessed March 28, 2018).

Gunawan, Depi. Media Indonesia. October 11th, 2017.http://mediaindonesia.com/news/read/126704/hewanternak-marak-dicuri-warga-desa-resah/2017-10-11 (Accessed March 28, 2018).

Haryanto, Adi. SindoNews. December 11, 2017. https://daerah.sindonews.com/read/1264830/21/13-kali-beraksikomplotan-pencuri-ternak arrested-1512997440 (Accessed March 28, 2018). 
THIIS PAGE INTENTIONALLY IEFT BLANK 